\title{
Serviço Social e educação popular: diálogos possíveis a partir de uma perspectiva crítica
}

\author{
Social Services and popular education: \\ possible dialogues from a critical perspective
}

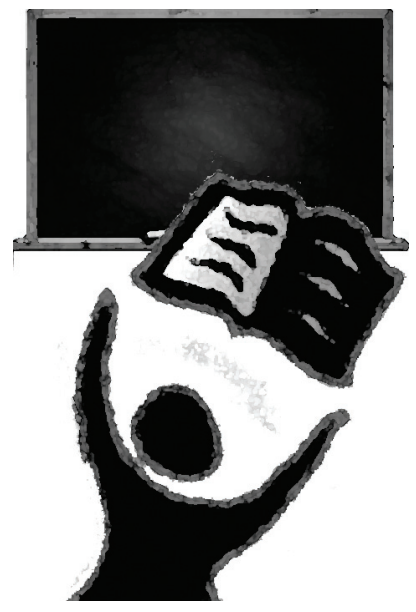

\section{Aline Maria Batista Machado*}

Resumo: O presente texto tem como objetivo principal retomar o debate acerca da educação popular enquanto temática e, simultaneamente, estratégia de ação relevante para o trabalho e a formação profissional do(a) assistente social, visto que ao mesmo tempo em que parece ter sido submersa do debate teórico-profissional ante o refluxo dos movimentos sociais, está presente no trabalho de campo desses profissionais, sobretudo porque esse paradigma educativo visa contribuir com o processo de conscientização e mobilização dos sujeitos sociais.

Palavras-chave: Educação popular. Serviço Social. Formação profissional. Mobilização social.

\begin{abstract}
This paper aims at resuming the debate on popular education as a theme and, at the same time, action strategy relevant to the job and professional training of social workers, because while it seems to have been submerged in the theoretical and professional debate due to the ebbing flow of the social movements, it is present in the field work of these professionals, especially because this educational paradigm aims at contributing to the process of awareness and mobilization of the social subjects.

Keywords: Popular education. Social Services. Professional background and social mobilization.

* Assistente social, doutora em Educação, professora adjunta do Departamento de Serviço Social e do Programa de Pós-Graduação em Educação da Universidade Federal da Paraíba — UFPB — João Pessoa/PB, Brasil. Atualmente coordena o Grupo de Estudos e Pesquisas em Educação Popular, Serviço Social e Movimentos Sociais - GEPEDUPSS e é membro do Conselho Estadual de Assistência Social da Paraíba. E-mail: alinemelo23@yahoo.com.br.
\end{abstract}




\section{Introdução}

educação popular constitui-se um paradigma educativo sistemati-
zado por Paulo Freire que visa contribuir com o processo de cons-
cientização e mobilização das classes subalternas, a partir de uma
teoria referenciada na realidade, na valorização dos saberes populares e de uma base ética e política voltada para a transformação social. Ela aposta em metodologias dialógicas que estimulam a luta coletiva pela emancipação humana e geralmente está presente no campo de atuação dos assistentes sociais que trabalham com comunidades, organização e mobilização popular, sobretudo em Organizações Não Governamentais — ONGs articuladas aos movimentos sociais, onde esse tipo de educação se refugiou desde o período da ditadura militar, visto que naquele contexto histórico passou a ser considerada uma prática educativa subversiva.

Mas não é de hoje que o Serviço Social dialoga com a área da educação popular. Conforme Netto (2002); Faleiros (2005), a aproximação do Serviço Social com as ideias de Paulo Freire na América Latina se dá no decorrer do Movimento de Reconceituação da profissão, ou seja, do movimento em que os assistentes sociais começam a compreender que a erosão do Serviço Social tradicional passa pela ruptura com as amarras imperialistas do sistema capitalista. Faleiros (2005, p. 25) afirma que devemos considerar "a influência, na formulação de um paradigma crítico, da pedagogia da conscientização elaborada por Paulo Freire". Ele destaca que "na perspectiva freireana é fundamental levar em conta a cultura do povo em qualquer processo de mudança, estabelecendo com ele um diálogo problematizador" (Ibidem).

Contudo, Netto (2002) explica que nesse período de reconceituação da profissão houve um ecletismo teórico em uma série de elaborações reconceitualizadas da América Latina. Inclusive naquelas que se fundamentavam no livro Pedagogia do oprimido, de Paulo Freire. Mas apesar dos equívocos teóricos, o autor reconhece que só "a partir de então criaram-se as bases, antes inexistentes, para pensar-se a profissão sob a lente de correntes marxistas" (p. 149). No Brasil, em particular, ao abordar o processo de renovação do Serviço Social, dividindo-o em três direções: "a perspectiva modernizadora", "a reatualização do conservadorismo" e "a intenção de ruptura", o autor aponta a incorporação das ideias freireanas nas formulações do chamado "método BH", isto é, do método que surge em Belo Horizonte (MG) entre 
1972 e 1975 como alternativa ao tradicionalismo no processo de "intenção de ruptura". Tanto é que os formuladores de Belo Horizonte consideravam que o objeto de sua atuação eram "a ação social da classe oprimida", seus objetivos meios eram "a conscientização, a capacitação e a organização" e seus objetivos fins eram a "transformação da sociedade e do homem".

Diante disso, Netto (2002) critica não só os teóricos que buscaram a congruência teórico-metodológica com o substrato das propostas de Freire, como a própria noção de "classe oprimida", uma vez que ela, "noção basicamente política, [...] sugere a remissão a uma estrutura social paradigmaticamente dicotômica, o que compromete [...] não apenas o seu potencial de orientação para intervenção, mas sobretudo a sua capacidade de decifrar o real” (p. 279). No entanto, não obstante o ecletismo e demais equívocos teóricos, o autor entende que no nosso país "o método BH" foi fundamental no processo de construção da "intenção de ruptura", pois, "foi além da crítica ideológica, da denúncia epistemológica e metodológica e da recusa das práticas próprias do tradicionalismo" (p. 276).

Cabe dizer que se o objeto de atuação da profissão fosse mesmo "a ação social da classe oprimida", como pensavam os formuladores do "método BH", os resultados da nossa intervenção ficariam totalmente submetidos à ação social dessa classe. Assim, ao longo dos anos a profissão foi se redefinindo, e hoje as diretrizes curriculares do curso de Serviço Social apontam como objeto de atuação da profissão as expressões da "questão social", onde se intervém na perspectiva da viabilização de direitos sociais.

Na década de 1980 a relação do Serviço Social latino-americano com a área da educação popular continua, porém, com o diferencial de que não se vivia mais a repressão do regime militar, o qual vigorou no Brasil do período 1964-85. Tanto que em junho de 1986, exatamente um ano após o fim da ditadura no nosso país, a Associação Brasileira de Ensino de Serviço Social Abess (hoje Associação Brasileira de Ensino e Pesquisa em Serviço Social - Abepss), promoveu juntamente com a Alaets/Celats/CFAS e Eness, o Seminário Nacional sobre Movimentos Sociais, Educação Popular e Serviço Social, o qual ocorreu na cidade de Salvador (BA), a fim de preparar a delegação brasileira para a Assembleia Geral da Alaets (Associação Latino-Americana de Escolas de Serviço Social), ao Encontro Prévio e ao XII Seminário Latino-Americano de Serviço Social realizados em Medellín, Colômbia, em julho do mesmo ano. 
Segundo a antiga Abess (1988, p. 4), naquele Seminário Nacional de 1986 foram destacados dois eixos de interesses dos assistentes sociais: um apontava as questões sociais, econômicas e políticas da América Latina, ressaltando-se aí as relações e perspectivas históricas do Brasil no nível do continente, e o outro era exatamente sobre os movimentos sociais e a educação popular. Este último eixo era visto como tema desafiador daquela conjuntura e por isso mesmo tido como fundamental "à prática contraditória dos profissionais de Serviço Social na América Latina, no esforço por uma articulação orgânica ao projeto popular alternativo".

Assim sendo, podemos dizer que a articulação entre as áreas de Serviço Social e educação popular surge aproximadamente no início da década de 1970. Apesar disso, atualmente a educação popular não está muito presente nos debates acadêmicos da área do Serviço Social. E quase não aparece mais nos eventos científicos dessa área, como podemos evidenciar nos anais dos principais congressos ou encontros da profissão dos últimos anos. Mas isso não significa que não haja assistentes sociais atuando com a educação popular e/ou debatendo-a em outras áreas, como saúde e educação por exemplo.

O fato é que apesar de o debate acerca desse tipo de educação ser incipiente na formação profissional do assistente social, as práticas em educação popular continuam presentes em seu campo de atuação, ocupando espaços coletivos em segmentos organizados da sociedade civil. Conforme Iamamoto (2002, p. 33), é muito importante ocupar esses espaços coletivos, especialmente a partir da conjuntura neoliberal, quando o bloco do poder passa a difundir e empreender o trabalho comunitário sob sua direção, tendo no voluntariado um especial protagonista. Algo que "representa uma ofensiva ideológica na construção e/ou consolidação da hegemonia das classes dominantes em um contexto econômico adverso" (Idem). Sobretudo porque a perspectiva da luta por direitos, estimulada tanto pela educação popular como pelo Serviço Social, passa a ser substituída pela perspectiva da refilantropização da questão social.

Diante disso, a autora afirma que se faz necessário reassumir o trabalho de base, de educação, mobilização e organização popular, que parece ter sido submerso do debate teórico-profissional ante o refluxo dos movimentos sociais e dos processos maciços de organização sindical, mas não do trabalho de campo. Em 2007 ela reitera seu posicionamento frente a esta questão na obra Serviço Social em tempo de capital fetiche: capital financeiro, trabalho e questão social, dizendo que é necessário ter clareza de que a qualidade da participação nos espaços 
coletivos em segmentos organizados da sociedade civil não está definida a priori porque são espaços de disputa. Em outras palavras, da mesma forma que os espaços coletivos (a exemplo dos Conselhos de Políticas da Saúde, da Assistência Social, dos Conselhos Tutelares, dos Conselhos de Direitos e até mesmo das ONGs) podem abrigar práticas assistencialistas, também podem apresentar práticas democráticas voltadas para a mobilização e a organização popular.

Nesse sentido, a provocação da autora, de que é preciso repensar o trabalho de mobilização e educação popular no nível da formação profissional, é extremamente oportuna, em especial quando explica que

repensar o trabalho de mobilização e educação popular [...] não se confunde com uma inócua ressurreição de um passado perdido. Exige uma releitura crítica da tradição profissional do Serviço Social, reapropriando-se das conquistas e habilitações perdidas no tempo e, ao mesmo tempo, superando-as, de modo a adequar a condução do trabalho profissional aos novos desafios do presente. (Iamamoto, 2002, p. 33)

Assim sendo, ampliar o debate acerca da importância da educação popular para o Serviço Social e realizar pesquisas no âmbito das ONGs e demais instituições que atuam com esse tipo de educação é fundamental para a formação e a prática dos estudantes e profissionais da área. Até porque, conforme Freire (2007, p. 103-105), “a educação popular posta em prática em termos amplos, profundos e radicais, numa sociedade de classe, se constitui como um nadar contra a correnteza”. O que converge com os princípios do Projeto Ético-Político Profissional do Assistente Social, que optou por vincular-se "ao processo de construção de uma nova ordem societária, sem dominação-exploração de classe, etnia e gênero" (CFESS, 1993, p. 11), ou seja, também nada contra a mesma correnteza, o sistema capitalista.

Diante do exposto, pretendemos apresentar aqui algumas considerações acerca da educação popular nos moldes da perspectiva freireana, seguido de algumas reflexões sobre a importância da metodologia desse tipo de educação para o trabalho e a formação profissional do assistente social. Inclusive porque se na prática esse profissional se defronta com possibilidades de atuar com a educação popular, o ideal é que ele saiba o que ela significa desde a sua formação acadêmica, e não depois dela. Além disso, a educação popular nos possibilita práticas mais críticas e democráticas, opostas a ações verticalizadas, em que só se considera o saber do profissional, restando ao seu público-alvo o mero papel de espectador, e não de sujeito social. 


\section{A educação popular}

As raízes da educação popular são genuinamente brasileiras. Elas emergem no Brasil no contexto histórico do Nacional Desenvolvimentismo (1930-64), sobretudo no governo do presidente Juscelino Kubitschek (1956-61), visto que nesse período de transição do capitalismo competitivo para o monopolista surge "um movimento de expressão popular em cujo interior se inscreveram as mais diversas iniciativas de cunho educativo" (Bezerra, 1984, p. 17). Se por um lado a ênfase no nacionalismo e no progresso da fase desenvolvimentista fazia com que as instituições estatais ou paraestatais e as frações sociais nitidamente elitistas promovessem movimentos educativos para "disciplinar o preenchimento do papel social das camadas populares no interior do modelo de sociedade mantido pelas elites" (Idem, p. 27), por outro lado o debate acerca de uma identidade cultural e a busca pela democratização da cultura permitiram a emergência de um movimento popular que posteriormente possibilitou a presença das expressões de cultura e de educação popular do setor universitário, o surgimento dos Centros Populares de Cultura - CPCs da UNE e das UEE e, paralelamente, as iniciativas da Igreja (como o Movimento de Educação de Base) e dos grupos de profissionais liberais (a exemplo dos Movimentos de Cultura Popular).

Segundo Bezerra (1984), as atividades educativas características dessa época dividem-se em três grupos de atividades: alfabetização, educação de base e cultura popular. Apesar de estarem relacionados entre si, a autora afirma que as origens dos dois primeiros grupos (alfabetização e educação de base) estavam mais ligadas à instrução, à transmissão do saber compatível com o progresso e vinculadas à insuficiência e à ineficácia do ensino formal e dos seus sistemas. Foi posteriormente que seus universos de trabalho seguiram no caminho pedagógico para conscientização das camadas populares, enquanto o último grupo (cultura popular) esteve, desde o início, voltado para "a afirmação de uma cultura verdadeiramente nacional, a luta contra a invasão cultural, contra o imperialismo e a desnacionalização, a democratização pela valorização da expressão cultural e política das camadas populares" (p. 33).

Diante desse contexto, a autora afirma que o conjunto de práticas de educação popular reveladas pelos movimentos educativos que se afirmam no período de 1959-64 estava predominantemente voltado para o exercício da cidadania, para afirmação e desempenho, pelas camadas populares, do papel que 
deveriam assumir no cenário sociopolítico; buscava a convocação de alinhamentos dos grupos populares em um movimento de resistência ao imperialismo, e não à integração dos indivíduos ao sistema e, ao mesmo tempo, propunha desvendar os conflitos sociais e o reconhecimento das tensões existentes em nome da construção de uma força de pressão suficiente para mudar as condições sociais postas.

Assim, é a partir dos movimentos educativos voltados para hegemonia dos setores populares do início dos anos de 1960 que nasce, no país, a educação popular sistematizada por Paulo Freire, o qual a define como a que,

substantivamente democrática, jamais separa do ensino dos conteúdos o desvelamento da realidade. É a que estimula a presença organizada das classes sociais populares na luta em favor da transformação democrática da sociedade, no sentido da superação das injustiças sociais. É a que respeita os educandos, não importa qual seja sua posição e classe e, ao mesmo tempo, leva em consideração, seriamente, o seu saber de experiência feito, a partir do qual trabalha o conhecimento com rigor de aproximação aos objetos. [...] É a que não considera suficiente mudar apenas as relações entre educadora e educandos, amaciando essas relações, mas, ao criticar e tentar ir além das tradições autoritárias [...] critica também a natureza autoritária e exploradora do capitalismo. (Freire, 2007, p. 103-105)

Nos moldes da perspectiva freireana essa forma de educação é, ainda, enquanto prática eminentemente política, a que se aproxima da comunidade e dos movimentos populares com os quais aprende para a eles poder ensinar também. Ademais, o elemento popular não se apresenta apenas para adjetivar um tipo específico de educação, mas para diferenciá-la como a que "é capaz de contribuir para a construção de direção política dos setores sociais que estão à margem do fazer político" (Melo Neto, 2004, p. 158). De acordo com este último autor, embora a categoria popular adquira uma plasticidade conceitual, ao pensá-la de forma dialética, no contexto de sua historicidade, algo é popular se tem origem nas postulações dos setores sociais majoritários da sociedade ou de setores comprometidos com suas lutas, exigindo-se que as medidas a serem tomadas beneficiem essas maiorias.

Essa proposta educacional surge, pois, no

terreno fértil das utopias de independência, autonomia e libertação, que propunham um modelo de desenvolvimento baseado na justiça social. Para esse modelo de edu- 
cação popular a conquista do Estado era fundamental. Porém esse processo foi interrompido pela brutal intervenção militarista e autoritária. A educação popular refugiou-se, então, nas Organizações Não Governamentais [ONGs] e, alguns casos, na clandestinidade. (Gadotti, 2000, p. 292)

Conforme o autor, desde então a educação popular tem se constituído num paradigma teórico que trata de codificar e descodificar os temas geradores das lutas populares, busca colaborar com os movimentos sociais e os partidos políticos que expressam essas lutas. Trata de diminuir o impacto da crise social na pobreza e de dar voz a indignação e desespero moral do pobre, do oprimido, do indígena, do camponês, da mulher, do negro, do analfabeto e do trabalhador industrial.

Cabe lembrar que outras formas de educação foram denominadas de popular, mas que na verdade eram populistas, pois, embora também fossem direcionadas às classes subalternas, não buscavam contribuir com a emancipação destas, e sim com a reprodução da ideologia dominante, ou seja, com "a ocultação de verdades, a distorção da razão de ser dos fatos que, explicados, revelados ou desvelados, trabalhariam contra os interesses dominantes" (Freire, 2007, p. 101), a exemplo do Movimento Brasileiro de Alfabetização - Mobral, que entre as décadas de 1970 e 1980 se preocupava apenas em alfabetizar o cidadão, e não em contribuir com o desenvolvimento de sua visão crítica. Até mesmo porque o interesse principal desse tipo de educação era com "o desenvolvimento das capacidades produtivas da população/força de trabalho em busca de maior rendimento socioeconômico (o progresso)" (Bezerra, 1984, p. 26).

Nessa perspectiva, voltada para o desenvolvimentismo do país e não para emancipação das classes subalternas, "a educação seria uma espécie de alavanca social com capacidade de tirar populações inteiras do estado de pobreza e atraso cultural [...] seria através da superação da ignorância que os outros dois males seriam sanados" (Idem, p. 28). Como se o atraso social fosse uma questão simplesmente educativa.

É evidente que a democratização da alfabetização das classes subalternas é algo extremamente importante para o desenvolvimento da sociedade, mas não é suficiente para que uma educação seja popular, isto é, problematizadora, crítica. Na perspectiva freireana é preciso que a educação popular vá além da democratização da alfabetização; deve estar voltada para a conscientização da população, conscientização de sua condição social e econômica na sociedade. Uma 
educação em que haja, conforme Gadotti (2000), um processo sistemático de participação na formação, fortalecimento e instrumentalização das práticas e dos movimentos populares com o objetivo de apoiar a passagem do saber popular ao saber orgânico, ou seja, do saber da comunidade ao saber de classe na comunidade.

O autor assinala que a grande utopia da educação popular dos anos 1960 visava à conquista do Estado e à mudança radical da política econômica e social. Hoje, o que se assiste, é a educação popular dispersando-se em milhares de pequenas experiências, perdendo aquela grande unidade teórica, mas ganhando em diversidade.

Contudo, diante dessa diversidade de práticas que vem se identificando como educação popular, emerge, por parte dos educadores desse campo, a preocupação com a qualidade de tais atividades. Um exemplo disso são as conclusões do Seminário Taller sobre educação popular na América Latina e no Caribe, realizado em La Paz, Bolívia, no ano de 1990, cujos registros no livro Educação popular - utopia latino-americana demonstraram que as maiores preocupações dos participantes desse seminário eram as crises tanto do discurso como da prática em educação popular, que se expressam, por um lado, na insuficiência do discurso para falar e dar conta da ação e, por outro, nos problemas que afetam as práticas e especificidades no contexto social e político da região. Tais análises não negam os avanços da educação popular. Entretanto, apontam os desafios que emergem para esse paradigma educativo em face da realidade contemporânea da América Latina.

A partir de um olhar acerca da especificidade e rigorosidade interna, os participantes do Seminário Taller tanto constataram uma rica variedade de práticas que se identificam como educação popular como a ausência de sistematizações de tais atividades, ou seja, o desconhecimento da qualidade destas.

O consenso dessas discussões reflete que, dada a tendência geral da educação popular, de um discurso ligado a uma leitura das dimensões estruturais da dominação e funcionamento da sociedade, restou pouco espaço para análises teóricas dos problemas cotidianos e processos de constituição da subjetividade dos sujeitos. O que demonstrou, para os participantes, um descuido no que tange à compreensão da natureza simbólica das práticas educativas, sua especificidade pedagógica e as características dos cenários e processos cotidianos nos quais estas transcorriam. 
O problema é que o foco na prática cotidiana desconectada do todo social oculta a realidade, uma vez que esta não se manifesta de maneira imediata, por meio da aparência. Ao se apegar à micronarrativa em detrimento da explicação globalizante, muitos educadores passam a considerar apenas a questão da cotidianidade e excluir a historicidade, a enfatizar a individualidade, a alteridade, a diferença regional, local, rejeitando as concepções pedagógicas direcionadas às mudanças estruturais.

Segundo Gadotti e Torres (1994), os debates do Seminário Taller visavam melhorar a qualidade dos processos educativos que vinham sendo implementados, o que implica, por um lado, analisar com maior profundidade os processos de aprendizagem que se promovem, o problema da transmissão de conhecimento e sua articulação com o saber popular, a transferência dos recursos simbólicos e materiais e a relação de autonomia ou dependência que estabelecem as Organizações Não Governamentais com as organizações sociais e por outro lado, constatar como o problema do Estado surge com importância no debate dos educadores populares.

Deve-se ressaltar, que nesse contexto da década de 1990 Paulo Freire já destacava a existência de um equívoco nos novos debates sobre a educação popular: o de que a "boa" educação popular é a que se despreocupa com o desvelamento da realidade, com a razão de ser dos fatos, reduzindo a prática educativa ao ensino puro dos conteúdos. "Este equívoco é tão carente de dialética quanto o seu contrário: o que reduz a prática educativa a puro exercício ideológico" (Freire, 2007, p. 110). Para ele, preocupar-se com o ensino puramente técnico, com a transmissão de um conjunto " $\mathrm{x}$ " de conhecimentos necessários às classes populares para a sua sobrevivência é típico do discurso neoliberal e, mais do que uma postura politicamente conservadora, esta é uma posição epistemologicamente insustentável.

\section{Alguns elementos constitutivos da educação popular e sua importância para a área do Serviço Social}

Como dissemos inicialmente, a educação popular aposta em metodologias que estimulam a luta coletiva pela emancipação humana. Aqui falamos em metodologias, no plural, porque, assim como o Serviço Social, não existe uma receita pronta e acabada para a prática em educação popular. Entretanto, há 
alguns elementos que a constituem e que, por isso mesmo, tanto nos possibilita orientar o profissional que pretende atuar na perspectiva da educação popular, como identificar se um profissional está de fato fazendo educação popular. Mas antes de abordá-los cabe ressaltar a relevância deles para a área do Serviço Social.

Na prática profissional do assistente social quase sempre se trabalha com comunidades carentes, seja em instituições públicas das esferas municipais, estaduais, federais, seja em instituições privadas, a exemplo das Organizações Não Governamentais (ONGs) e de empresas que desenvolvem projetos voltados para "responsabilidade social", marketing social.

$O$ fato é que esse profissional lida cotidianamente com variadas expressões da questão social, porém normalmente perde a oportunidade de estimular a organização e mobilização popular, seja por falta de tempo, iniciativa ou mesmo desconhecimento, ou seja, em geral detectam essa necessidade mas não sabem por onde começar, outros detectam e até intervêm, no entanto terminam adotando práticas antidemocráticas. Isto é, sem consulta ou diálogo com a população, embarcam em projetos verticalizados, impostos pelas instituições ou empresas em que trabalham, acreditando que estão contribuindo com a organização daquelas comunidades, mas na verdade o estímulo à mobilização popular passa longe. A exemplo de vários projetos de habitação que emergem em prefeituras municipais visando deslocar comunidades inteiras para protegê-las de determinadas áreas de risco ambiental, mas que sequer se preocupam em ouvir as sugestões e propostas das famílias envolvidas nesse processo, as quais muitas vezes retornam para a comunidade de risco alegando que os locais para onde foram transferidas são muito distantes, inclusive de seus trabalhos, ou porque sentem faltam daqueles que foram seus vizinhos há mais de vinte anos, ou porque na atual comunidade estão correndo riscos maiores, pois agora convivem com pessoas violentas ou envolvidas com o tráfico de drogas, algo que não existia em sua antiga comunidade, dentre várias outras justificativas que poderiam ter sido evitadas se houvesse um canal de comunicação dialógica com a comunidade, e não uma imposição. Ou seja, é o tipo de situação em que só se leva em conta o risco ambiental, o que é importante, porém há uma série de riscos sociais e psicológicos que também devem ser levados em consideração na hora de se criar, executar e avaliar um projeto de desenvolvimento social.

Diante desse e de muitos outros exemplos advindos de situações reais, entendemos que a educação popular é fundamental para a formação de assis- 
tentes sociais, pois por meio dela é possível uma prática mais dialógica, democrática, que impulsiona processos de conscientização, organização, participação e mobilização, levando-se em conta o saber popular, a autonomia e a diversidade cultural. Portanto, dentre os vários elementos que compõem essa educação destacaremos os que consideramos essencias para se pensar e realizar ações educacionais populares voltadas para a hegemonia das classes subalternas, quais sejam: a práxis, a conscientização, o diálogo, o conhecimento popular, a hegemonia e a participação.

Ao discorrer sobre a origem do termo práxis, Vázquez (1977) vai buscar na Grécia Antiga o significado semântico da palavra práxis, a qual transcreve um termo grego, $\pi \rho \alpha \xi ı \zeta$, utilizado na Antiguidade para designar a ação propriamente dita. Uma ação que tem seu fim em si mesma, que não cria ou produz um objeto alheio ao agente ou a sua atividade. Um exemplo dado é a ação moral, intersubjetiva, bem como a atividade política do cidadão tanto nos debates como nas deliberações da comunidade. Por outro lado, a ação que cria um ob-

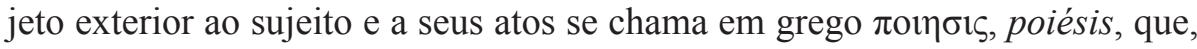
embora no idioma português expresse poesia, aí significa produção ou fabricação, a exemplo da atividade do artesão. Em outros termos, trata-se da atividade prática que produz.

Segundo Konder (1992), para Aristóteles existiam três tipos de atividades humanas fundamentais: a práxis, a poiésis e a theoria. A práxis era encarada como atividade ética e política, distinta da atividade produtiva, que era a poiésis, enquanto a teoria representava exclusivamente a busca da verdade.

Vázquez (1977) afirma que nessa época o mundo grego, assim como o romano, ignorava ou repelia o mundo produtivo, pois era considerado próprio dos escravos, enquanto o teórico destinava-se aos homens livres, determinando a ruptura entre a ciência e a produção. E nessa divisão social do trabalho exaltava-se a atividade contemplativa, intelectual. Dessa forma, Aristóteles, assim como Platão, até admitia a legitimidade da práxis política, mas sempre com um nível inferior à vida intelectual, posto que para ambos o ser humano só se realiza verdadeiramente na vida teorética.

A Idade Média segue no ritmo da Antiguidade, no que diz respeito à oposição entre teoria e prática, uma vez que, apesar da desintegração da escravidão romana, os camponeses tornaram-se servos dos nobres feudais. É somente na Modernidade que a consciência filosófica da práxis sofre uma mudança radical. 
A partir daí reivindica-se a dignidade humana não só pela ação contemplativa, mas também pela ação produtiva. Mais tarde, porém, Rousseau nega a positividade do trabalho produtivo, sendo o primeiro a relacionar a transformação da natureza com a transformação negativa do homem, uma vez que ao refletir sobre as consequências do progresso, conclui que a transformação da natureza só serviu para degradar o homem, antecipando ideias que posteriormente aparecerão em Marx.

Embora a práxis na concepção de Marx deite raízes nos Manuscritos econômico-filosóficos de 1844, é em A ideologia alemã, de 1845, que, juntamente com seu amigo e parceiro intelectual Friedrich Engels, apresenta uma sistematização da práxis revolucionária.

A práxis no sentido que lhe atribui Marx, ação transformadora, revolucionária, transcende a condição de simples ação. Mas também não expressa nenhuma ação transformadora, posto que está aprofundada numa concepção dialética da história e da sociedade, unindo pensamento consciente e ação real, com vistas à transformação radical da sociedade. Todavia, quando se trata de abordar a práxis a partir de uma consciência filosófica, encarando-a como atividade humana que transforma o mundo natural e social, Vázquez (1977) indica como marcos fundamentais não apenas a teoria de Marx, mas também as de Hegel e Feuerbach. Destarte, embora Marx tenha sido discípulo de Hegel, opôs-se a ele ao promover uma nova inversão metodológica, ao estabelecer que "não é a consciência que determina a vida, mas a vida é que determina a consciência" (Marx e Engels, 2005, p. 52).

Ao estabelecer que a fonte real humana é a práxis e não a consciência, Marx se rebela contra o mundo das ideias, dos dogmas, das entidades imaginárias. Com ele "atam-se os fios procedentes de Hegel, Feuerbach, dos economistas ingleses e das doutrinas socialistas de seu tempo" (Vázquez, 1977, p. 38). Emergindo, assim, uma concepção marxista da práxis, cuja síntese une, em uma mesma categoria filosófica, theoria, práxis e poiésis. Portanto, a práxis marxista pode ser definida como a "atividade concreta pela qual os sujeitos humanos se afirmam no mundo, modificando a realidade objetiva e, para poderem alterá-la, transformam-se a si mesmos. É a ação que [...] precisa da reflexão, da teoria; e é a teoria que remete à ação" (Konder, 1992, p. 115). Nessa perspectiva, desde Marx até os tempos atuais entende-se que a práxis transcende a prática pragmática, individual e autossuficiente. 
No que se refere ao segundo elemento constituinte da educação popular que destacamos aqui, conscientização, Freire (1979, p. 114-115) afirma:

A conscientização é [...] um ato de conhecimento. Implica um desvelamento da realidade com o qual vou me aprofundando [...] para desvelar a sua razão de ser [...]. O processo de conscientização implica [...] um ato lógico de conhecimento e não transferência de conhecimento. [...] não se pode basear na crença de que é dentro da consciência que se opera a transformação do mundo, a criação do mundo. É dentro do próprio mundo que, na história, através da práxis que se dá o processo de transformação.

O referido autor afirma que o vocábulo conscientização foi criado por uma equipe de professores do Instituto Superior de Estudos Brasileiros - Iseb, entre os quais cita o filósofo Álvaro Vieira Pinto e o professor Guerreiro Ramos, no início dos anos de 1960. Ao analisar as concepções a respeito da educação, Pinto (2003) apresenta dois tipos de consciência, a ingênua e a crítica. Segundo esse autor, a consciência ingênua acredita que suas ideias vêm dela mesma, não provém da realidade, ou seja, que têm origem em ideias anteriores. Ela pode refletir sobre si mesma, porém não chega a ser uma autoconsciência. Já a consciência crítica é a representação mental do mundo exterior e de si, acompanhada da clara percepção dos condicionantes objetivos que a fazem ter tal representação. Quando reflete sobre si, torna-se verdadeiramente autoconsciência, pelo fato de perceber seu conteúdo acompanhado da representação.

Para Freire (1979, p. 113), a "conscientização [...] é um processo humano que se instaura quando a consciência se torna reflexiva". Entretanto, ele explica que mais do que a tomada de consciência, que resulta do simples fato de o homem ter uma consciência reflexiva, é o aprofundamento da tomada de consciência, que significa a ultrapassagem do que chama de forma cotidiana de abordagem do mundo - consciência comum nos termos de Vázquez (1977) ou ingênua nos moldes de Pinto (2003) — para uma forma crítica de abordagem do mundo, na qual se busca não apenas o desvelamento, mas também a transformação da realidade.

"A conscientização produz a desmitologização. [...] Por isso mesmo a conscientização é o olhar mais crítico possível da realidade, que a desvela para conhecê-la e para conhecer os mitos que enganam e ajudam a manter a realidade da estrutura dominante" (Freire, 2001, p. 33). 
Conforme o autor, a conscientização, enquanto atitude crítica do ser humano na história, é um processo inacabado e contínuo. Está ligada à utopia, não sendo esta irrealizável. "Para mim o utópico não é o irrealizável; a utopia não é o idealismo, é a dialetização dos atos de denunciar e anunciar, o ato de denunciar a estrutura desumanizante e de anunciar a estrutura humanizante. Por esta razão a utopia é também um compromisso histórico" (Freire, 2001, p. 32). De modo que, "a partir do momento em que denunciamos uma estrutura desumanizante sem nos comprometermos com a realidade, a partir do momento em que chegamos à conscientização do projeto, se deixarmos de ser utópicos, nos burocratizamos" (Idem, p. 33).

$\mathrm{O}$ autor recorre às ideias de Marx para ajudá-lo a entender melhor a problemática histórica global das camadas populares que ele já vinha trabalhando, tomando a práxis - categoria central da filosofia marxista - uma das categorias fundamentais da educação popular, pois compreende que a superação da contradição "opressor-oprimido" não pode ser superada apenas idealisticamente (no nível da consciência, da subjetividade), mas também objetivamente. "É atuando que posso transformar meu anteprojeto em projeto; [...] que se faz projeto por meio da práxis" (Freire, 2001, p. 32).

Conforme o autor, "o homem não pode participar ativamente na história, na sociedade, na transformação da realidade, se não é auxiliado a tomar consciência da realidade e de sua própria capacidade para transformá-la" (Idem, p. 46). Implica, pois, que "a realidade não pode ser modificada, senão quando o homem descobre que é modificável e que ele pode fazê-lo" (Idem). É aqui que podemos perceber o grande diferencial entre o pensamento freireano e o marxiano, pois Marx, ao contrário de Freire, ainda que também aponte a necessidade de "uma transformação ampla dos homens para a criação em massa da consciência comunista" (Marx e Engels, 2005, p. 106), entende que essa transformação dos homens não passa inicialmente pela tomada de consciência da realidade, mas sim por um movimento prático, a revolução. Em outras palavras, somente após uma revolução social é que ocorreria a conscientização ou, nos termos do próprio Marx, a consciência comunista, pois para ele: "A questão de atribuir ao pensamento humano uma verdade objetiva não é uma questão teórica, mas prática. É na práxis que o homem deve demonstrar a verdade, isto é, a realidade e a força, o caráter terreno de seu pensamento" (Marx, 2005, p. 120). Até porque “a 'libertação' é um ato histórico, e não um ato de pensamento, e é realizado por condições históricas" (Idem, p. 73). 
Desse modo, enquanto para Freire a transformação do homem passa inicialmente pela consciência crítica acerca da realidade concreta, visto que essa tomada de consciência o levará à mobilização social, bem como à luta de classes ou até mesmo a uma revolução social, para Marx o processo é inverso, visto que a transformação do homem passa inicialmente pela revolução social, pois é esta que permitirá a consciência crítica em massa.

Faz-se necessário uma transformação ampla dos homens para a criação em massa dessa consciência comunista e também para o êxito da causa em si. Essa transformação só será possível por meio de um movimento prático, uma revolução; essa revolução é necessária, entretanto, não só por ser a única maneira de derrotar a classe dominante, mas também porque somente uma revolução possibilitará à classe que derruba a outra varrer toda podridão do sistema antigo e se tornar capaz de instaurar a sociedade sobre novos fundamentos. (Marx e Engels, 2005, p. 106)

Feita essas diferenciações, para que não corramos o risco de cair no ecletismo teórico, gostaríamos de esclarecer que concordamos com Marx que a "libertação é um ato histórico, e não um ato de pensamento" e sobretudo que a transformação social se dá pela ação, e não pela conscientização. Contudo, compreendemos que no âmbito da educação, entendida aqui como "uma forma de intervenção no mundo" (Freire, 2005, p. 98), é fundamental uma prática pedagógica que estimule o processo de conscientização, e não de alienação. Daí nos acostarmos na ideia de Freire (2001) de que é preciso fazer da conscientização o primeiro objetivo da educação, provocando uma atitude crítica, de reflexão, que comprometa a ação, sem submeter, domesticar, adaptar o ser humano, sem ajustá-lo à sociedade, e, sim, promovendo-o em sua própria linha de raciocínio. Ademais, a educação popular proposta por Freire estimula a práxis social a partir de uma leitura crítica da realidade concreta.

Obviamente que a sociedade capitalista não tem interesse em uma educação que contribua com o processo de conscientização, pois desvelá-la significa ameaçá-la. Como acrescenta Pinto (2003), essa sociedade visa educar os analfabetos não para criar condições de participação crítica, mas para permitir que esta se faça em patamares mais identificados com a hegemonia da classe dominante, cumprindo o que julga ser um dever moral, quando na verdade não passa de uma exigência econômica.

O elemento diálogo, por sua vez, é fundamental numa educação popular. Ele é o "encontro que solidariza a reflexão e a ação de seus sujeitos orientados 
para o mundo que deve ser transformado" (Freire, 1979b, p. 121), portanto, “o encontro dos homens para ser mais" (Freire, 1977, p. 95). Até porque o diálogo não é o momento onde só um expõe suas ideias, mas sim o momento em que dois ou mais trocam, aprofundam e lançam ideias.

De acordo com Freire (1977), para haver um efetivo diálogo entre as partes que dialogam é preciso mais do que troca de ideias; é necessário humildade na troca de ideias, a fim de que não se veja no outro apenas um ignorante. Ademais, para que o diálogo seja verdadeiro, faz-se necessário o pensar crítico; caso contrário, o que parece diálogo ou troca de ideias pode, na verdade, ser uma manipulação de ideias.

Assim sendo, na perspectiva freireana uma educação dialógica não permite que o educador imponha sua visão de mundo ao educando, mas sim que dialogue com ele sobre a sua e a dele, que problematize a realidade concreta do educando, a fim de que este perceba se sua visão de mundo reflete a sua real situação de mundo. Daí a importância de educação popular ser dialógica, ou seja, ter o diálogo como um de seus constituintes. Até mesmo porque o processo de conscientização que propõe "não é imposição, não é manipulação. Eu não posso impor ao outro minhas opiniões; só posso convidá-lo a conversar, a discutir. Impor aos outros minha maneira de pensar é uma forma de aliená-lo, de manipulá-lo" (Freire, 1979b, p. 104).

Nesse sentido, não cabe ao educador que se pretende dialógico e problematizador impor conteúdos, mas sim devolver de forma organizada e sistematizada conteúdos que ele apreendeu de forma desestruturada da realidade e dos saberes dos próprios educandos. Do mesmo modo, uma liderança revolucionária, que não seja dialógica com as massas, ou mantém a "sombra" do dominador dentro de si e não é revolucionário, ou está redondamente equivocada e, presa de uma sectarização indiscutivelmente mórbida, também não é revolucionária (Freire, 1977, p. 143-144).

Portanto, o principal nesse debate é que, embora o elemento principal da educação popular seja a práxis, "sem o diálogo com os oprimidos, não é possível uma práxis autêntica nem para estes" (Idem, p. 142) nem para eles. Freire (2005) também afirma que na educação popular o ensinar exige respeito aos saberes das classes populares. Aí temos outro elemento constituinte desse tipo de educação, o conhecimento popular. No âmbito do ensino deve-se, inclusive, "discutir com os alunos a razão de ser de alguns desses saberes em relação com 
o ensino dos conteúdos" (Freire, 2005, p. 30). Deve-se também aproveitar a experiência que têm os educandos das classes populares de viver em áreas da cidade descuidadas pelo poder público, ou seja, "estabelecer uma 'intimidade' entre os saberes curriculares fundamentais e a experiência que eles têm como indivíduos" (Idem).

O conhecimento popular ou saber popular se diferencia das outras formas de conhecimentos ou saberes não pela questão da veracidade, nem pela natureza do objeto conhecido, mas sim pela forma como procura explicar a realidade. Em geral se afirma que ele é adquirido com o tempo, ou seja, a partir das experiências vivenciadas cotidianamente, e repassado de geração em geração ao longo da história.

Conforme Ferrari (1974), o conhecimento popular é valorativo, reflexivo, assistemático, verificável, falível e inexato. Valorativo porque se fundamenta numa seleção operada com base nos estados de ânimos e emoções da vida diária; reflexivo porque apreende a realidade, embora seja limitado pela familiaridade com o objeto, não podendo ser reduzido a uma formulação geral; assistemático porque se baseia na "organização" particular das experiências próprias do sujeito cognoscente; verificável porque se pode perceber no dia a dia, mas limitado ao âmbito da vida diária; e, falível e inexato porque se conforma com a aparência e com o que se ouviu dizer a respeito do objeto, não permitindo a formulação de hipóteses sobre a existência de fenômenos situados além das percepções objetivas.

Ao assinalar os saberes necessários à prática educativa, Freire (2005, p. 29) afirma que: "Pensar certo do ponto de vista do professor, [...] implica o respeito ao senso comum no processo de sua necessária superação". O que significa que o conhecimento popular, enquanto senso comum, ao mesmo tempo em que deve ser respeitado, também deve transitar da forma cotidiana de abordagem do mundo para a forma crítica de abordagem do mundo. Assim sendo, a superação do senso comum é necessária no processo educativo crítico porque possibilita a transição para o processo de conscientização.

No que diz respeito ao elemento hegemonia, é importante destacar que Gramsci (1891-1937) é considerado o grande responsável pela noção de hegemonia, cuja importância é enfatizada no início do século XX, primeiramente em sua obra A questão meridional e depois nos Cadernos do cárcere. Entretanto, Portelli (1977) afirma que ele recusa a paternidade do conceito por perceber a origem dela na obra e ação política de um outro marxista, Lênin. 
Gruppi (2000, p. 11) explica que o debate sobre hegemonia é o ponto de confluência entre Lênin e Gramsci, sendo este último o que mais insistiu sobre o seu conceito. Diz ainda que quando Gramsci fala de hegemonia, refere-se ora à capacidade dirigente, ora à simultaneidade entre direção e dominação, enquanto Lênin, ao contrário, entende por hegemonia sobretudo a função dirigente. No entanto, para ambos é impossível hegemonia sem a unidade entre teoria e ação, porque ela "só se dá com a plena consciência teórica e cultural da própria ação; com aquela consciência que é o único modo de se tornar possível a coerência da ação; de emprestar-lhe uma perspectiva, superando a imediaticidade empírica". Daí a compreensão de hegemonia não apenas como direção política, mas também como direção moral, cultural e ideológica.

Além de relacionar hegemonia ora à capacidade dirigente, ora à simultaneidade entre direção e dominação, Gramsci (2004) entende que hegemonia também tem a ver com o consenso "espontâneo" dado pelas grandes massas da população à orientação impressa pelo fundamental dominante à vida social, consenso que nasce do prestígio e da confiança obtidos pelo grupo dominante por causa de sua posição e função no mundo da produção. Em vista disso, Coutinho (1981) assevera que na perspectiva gramsciana a hegemonia da classe trabalhadora não deve limitar-se à coerção, mas fundar-se especialmente sobre o consenso das massas. Assim sendo, a construção da hegemonia dos setores populares também passa pela conscientização de que a hegemonia significa

determinar os traços específicos de uma condição histórica, de um processo, tornar-se protagonista de reivindicações que são de outros estratos sociais, da solução das mesmas, de modo a unir em torno de si esses estratos, realizando com eles uma aliança na luta contra o capitalismo e, desse modo, isolando o próprio capitalismo. [...] É a capacidade de unificar através da ideologia e de conservar unido um bloco social que não é homogêneo, mas sim marcado por profundas contradições de classe. (Gruppi, 2000, p. 59-70)

Para Gramsci (2004), a sociedade é um bloco histórico composto por uma estrutura, que é o conjunto das forças sociais e do mundo da produção, e uma superestrutura, isto é, o reflexo do conjunto das relações sociais de produção, conjunto este composto por duas esferas que formam o Estado ampliado, a sociedade civil e a sociedade política. Então, quando fala apenas da sociedade política refere-se ao Estado no sentido estrito, e quando aborda apenas a sociedade civil significa "o conjunto de organismos designados 
vulgarmente privados [...] que corresponde à função de hegemonia que o grupo dominante exerce em toda a sociedade" (p. 20-21).

Dessa forma, se é certo a afirmação de que a sociedade civil possui uma função de hegemonia, isso implica dizer que possui capacidade de direção e dominação política, moral, cultural, ideológica e que, portanto, "o estudo gramscista da sociedade civil e da hegemonia tem por objetivo justamente sublinhar a importância da direção cultural e ideológica" (Portelli, 1977, p. 63). Traçando sua contribuição original ao desenvolvimento e renovação do marxismo, ao mesmo tempo em que explica a sociedade a partir da estrutura (base econômica), percebe que é nas atividades superestruturais (base ético-política) que se traduzem e resolvem as contradições. Há, portanto, uma relação dialética entre estrutura e superestrutura, e não uma hierarquia ou primazia de uma sobre a outra.

A análise gramsciana identifica três tipos de grupos sociais presentes no bloco histórico: 1) a classe que dirige o sistema hegemônico; 2) os grupos auxiliares que servem de base social à hegemonia e 3) os excluídos do sistema hegemônico. Pode-se dizer que os intelectuais — responsáveis pelo vínculo entre estrutura e superestrutura - fazem parte do segundo grupo, já que exercem funções subalternas ora à hegemonia social (consenso "espontâneo" das massas), ora ao governo político (aparelho de coerção estatal no qual desaparece o consenso "espontâneo").

A supremacia de um grupo social se manifesta de dois modos, como dominação e como direção intelectual e moral. Um grupo social é dominante dos grupos adversários, que tende a liquidar ou a submeter inclusive com a força armada, e é dirigente dos grupos afins e aliados. Um grupo social pode, e mesmo deve, ser dirigente já antes de conquistar o poder governamental. É essa uma das condições principais para a própria conquista do poder. Depois, quando exerce o poder, e mesmo quando o mantém fortemente sob controle, torna-se dominante, mas deve continuar a ser dirigente. (Gramsci, apud Gruppi, 2000, p. 78-79)

Nessa passagem, o autor afirma que Gramsci demonstra uma visão dinâmica do processo segundo o qual se formam e se dissolvem as hegemonias. $\mathrm{O}$ autor esclarece que para concepção gramsciana a conquista da hegemonia ocorre quando desaparece a capacidade dirigente da classe que até então detém o poder político, quando sua supremacia entra em crise mesmo que se mantenha a dominação. E isso acontece quando a referida classe não sabe mais verdadei- 
ramente dirigir, isto é, resolver os problemas da coletividade, quando a concepção de mundo que ela conseguira afirmar passa a ser rechaçada, o que pode levar a classe até então subalterna a tornar-se dirigente se, e somente se, esta souber indicar, de modo concreto, a solução para os problemas e, além disso, possuir uma concepção de mundo que conquiste novos adeptos, capaz de unificar o alinhamento que se forma em torno dela.

Em seus estudos Gramsci sempre chamou a atenção para o desenvolvimento político do conceito de hegemonia, por entender que ele representa progresso filosófico e político-prático, “já que implica e supõe necessariamente uma unidade intelectual e uma ética adequadas a uma concepção do real que superou o senso comum e tornou-se crítica" (Gramsci, 1995, p. 21). Ele assevera que a compreensão crítica de si mesmo é obtida por meio de uma luta de hegemonias políticas, de direções contrastantes, primeiro no campo da ética e depois no da política, atingindo uma elaboração superior do real.

A consciência de fazer parte de uma determinada força hegemônica (isto é, a consciência política) é a primeira fase de uma autoconsciência, na qual a teoria e prática finalmente se unificam. Portanto, também a unidade de teoria e prática não é um fato mecânico, mas um devenir histórico, que tem a sua fase elementar e primitiva [...] e progride até à possessão real e completa de uma concepção do mundo coerente e unitária (Gramsci, 1995, p. 21).

Por compreender que os intelectuais representam a tradição cultural de um povo, o autor afirma que uma hegemonia se constrói quando tem os seus próprios quadros, os seus próprios elaboradores, ou seja, os seus intelectuais, os construtores e defensores de teorias, concepções de mundo que servem de base a uma direção política, econômica, social e cultural. Contudo, reconhece que o processo de criação de intelectuais não é uma tarefa fácil; é um processo longo, difícil, cheio de contradições, de avanços e de recuos, de cisões e de agrupamento. Gramsci (1995) também admite que o grupo social de intelectuais é flexível, mas muito resistente; sua função dá sustentabilidade ao bloco histórico. Em vista disso, sua desagregação contribui para a derrocada de tal bloco. E, embora nenhuma sociedade ou bloco histórico deixe de existir antes de haver expressado todo o seu conteúdo potencial, seu desaparecimento ocorre no momento em que uma crise de estrutura (base econômica) gera uma crise orgânica ou crise de hegemonia, isto é, gera uma ruptura com a superestrutura (base ético-política). A responsabilidade dos intelectuais, de manter o vínculo entre 
estrutura e superestrutura, é, portanto, fundamental para a manutenção de uma hegemonia.

Agora vejamos o último elemento que destacamos como constituinte da educação popular, a participação, que como processo histórico, como mecanismo mobilizador e dinamizador de recursos e situações "representa a possibilidade de construção de uma cultura política no Brasil capaz de conferir visibilidade aos grupos sociais tradicionalmente excluídos do exercício decisório e do usufruto satisfatório dos bens socialmente produzidos" (Campos e Maciel, 1997, p. 150). Segundo Nogueira (2004), ainda que nem toda participação social seja imediatamente política, não há participação que não se oriente por algum tipo de relação com o poder, tanto com o poder de outros atores quanto com o de determinados centros organizacionais e decisórios. Esse autor afirma que nas duas últimas décadas do século XX o Brasil assistiu à afirmação categórica da ideia de participação no campo da gestão pública, refletindo, por um lado, o avanço da democratização e da diferenciação social após o longo período de autoritarismo imposto pela ditadura militar e, por outro, a progressiva valorização da democracia participativa. Se desde o arranque desenvolvimentista, entre as décadas de 1950 e 1960, prevalecia a centralização decisória, havia a convicção de que

processos participativos ou, mais genericamente, mecanismos de consulta popular, negociação e formação ampliada de consensos, agiriam "contra" o crescimento econômico, na medida em que dificultariam a tomada rápida de decisões e, com isso, prolongariam indevidamente o tempo de formulação e de implementação de políticas. Pouco a pouco, a opinião prevalecente foi-se deslocando para o lado oposto, com o correspondente reconhecimento de que a participação [...] seria particularmente relevante no fornecimento de sustentabilidade às políticas públicas e ao próprio desenvolvimento. Os processos participativos converteram-se, assim, em recurso estratégico do desenvolvimento sustentável e da formulação de políticas públicas. (Nogueira, 2004, p. 117-118)

Essa transição da centralização decisória à aceitação da ideia de processos participativos é acolhida por distintas correntes teóricas, partidos políticos e pelas agências internacionais de financiamentos. Conforme Nogueira (2004), um experimento que se revelou particularmente forte no Brasil foi o orçamento participativo. Apesar disso, o autor afirma que a aceitação de mecanismos participativos na gestão pública deixou de lado nuances teóricas relevantes e deu pouca atenção a certas implicações práticas. 
Se entre os anos de 1970 e 1980 falava-se em participação como veículo privilegiado de pressão popular, "articulada em torno de organizações coletivas, com uma clivagem de classe em torno de projetos e interesses mais universais" (Simionatto e Nogueira, 2001, p. 154), o que se tem a partir dos anos de 1990 é o discurso da participação "como expressão de práticas sociais democráticas interessadas em superar os gargalos da burocracia pública e em alcançar soluções positivas para os diferentes problemas comunitários" (Nogueira, 2004, p. 121).

De acordo com Simionatto e Nogueira (2001), de tempos em tempos a preocupação com o tema da participação ressurge assentada em pressupostos ideopolíticos, ora progressistas ora conservadores, e essa mudança entre as décadas de 1970 e 1990 acima mencionada se deve à articulação entre Estado e mercado, que recoloca o tema da participação no âmbito da política com um significado instrumental e reducionista, incentivando a sociedade civil a substituir as funções sociais do Estado em nome de um "dever cívico de solidariedade", fazendo com que percam de vista as conquistas democráticas das camadas de classe subalternizadas e deixem de se organizar conscientemente em torno da hegemonia dos setores populares. Para as autoras, reatualiza-se um discurso participacionista veiculado em épocas passadas, com conteúdos acríticos e aclassistas, vinculados a uma ideia de participação restrita em associações organizativas e associativas, que lutam pela solução de carências imediatas, encobrindo as questões estruturais que alicerçam a desigualdade social.

Tomando por base o mundo moderno, ou seja, o mundo da sociedade de classes, do capitalismo e do Estado democrático representativo, Nogueira (2004) ressalta quatro grandes modalidades de participação: assistencialista, corporativa, eleitoral e política. De modo geral, a participação assistencialista é aquela de natureza filantrópica ou solidária; a corporativa dedica-se à defesa de interesses específicos de determinados grupos sociais ou de categorias profissionais; a eleitoral é a que não visa apenas a defesa de interesses particulares, mas interfere diretamente na governabilidade e tem efeitos que dizem respeito a toda a coletividade, e a política inclui, complementa e supera tanto a eleitoral, quanto a participação corporativa. Ela se realiza tendo em vista a comunidade como um todo, a organização da vida social em seu conjunto, ou seja, o Estado. Por intermédio da participação política, indivíduos e grupos interferem para fazer com que diferenças e interesses se explicitem num terreno comum organizado por leis e instituições, bem como para fazer com que o poder se demo- 
cratize e seja compartilhado. Em vista disso, esse tipo de participação consolida, protege e dinamiza a cidadania.

O tema da participação tem, portanto, "forte conteúdo ideológico e comporta diferentes conceitos e definições” (Nogueira, 2004, p. 129). Assim sendo, comungamos com a perspectiva freireana por insistir que a participação comunitária ou popular não deve significar a omissão do Estado.

Os grupos populares certamente têm o direito de organizar-se [...]. Têm o direito inclusive de exigir do Estado, através de convênios de natureza nada paternalista, colaboração. Precisam, contudo, estar advertidos de que sua tarefa não é substituir o Estado no seu dever de atender às camadas populares. (Freire, 2007, p. 78)

A nosso ver, a relação entre a educação popular e a participação é dialética, pois ao mesmo tempo em que esse tipo de educação incentiva a participação política, esta pode estimular a luta por uma educação popular, tendo em vista que a participação, embora não leve automaticamente à resolução de problemas sociais, possui grande importância "na socialização política, na construção da representação de interesses, na ampliação da cidadania e na construção de um projeto de sociedade mais justa e democrática" (Simionatto e Nogueira, 2001, p. 152-153).

Daí entendermos que a soma desses elementos (práxis, conscientização, diálogo, conhecimento popular, hegemonia, participação) e outros que não foram abordados aqui, mas que são constituintes da educação popular, têm muito a nos ensinar, principalmente pelo seu comprometimento com a libertação da classe trabalhadora, algo central no Projeto Ético-Político do Serviço Social, que reconhece a liberdade como valor ético central.

\section{À guisa de conclusão}

No âmbito do Serviço Social, Iamamoto (2010, p. 200) afirma que os assistentes sociais precisam ter o conhecimento criterioso dos processos sociais e de sua vivência pelos indivíduos sociais, visto que isso poderá alimentar ações inovadoras. Aliás, tal "conhecimento é pré-requisito para impulsionar a consciência crítica e uma cultura pública democrática”. Com essa afirmação a autora tanto estimula o desenvolvimento de pesquisas e projetos que favoreçam 
o conhecimento do modo de vida e de trabalho dos segmentos populacionais atendidos, como estimula os profissionais a impulsionarem a consciência política desses mesmos segmentos. Até porque a consciência política significa "a consciência de fazer parte de uma determinada força hegemônica é a primeira fase de uma autoconsciência, na qual a teoria e prática finalmente se unificam" (Gramsci, 1995, p. 21).

Mas em termos técnico-operativos, de que forma se estimula a consciência política dos sujeitos sociais? De que maneira podemos impulsionar uma cultura pública democrática? E o assistente social vem intervindo nessa perspectiva? Se sim, como vem se dando essa intervenção?

Quanto ao primeiro e o segundo questionamentos, podemos dizer que nisso (estímulo à consciência crítica e a uma cultura democrática) a metodologia da educação popular é fundamental, pois ao mesmo tempo em que busca desvelar a realidade social e contribuir com o desenvolvimento da capacidade crítica das classes subalternas, luta pelo protagonismo dos sujeitos sociais. $\mathrm{O}$ que significa que esse tipo de educação, enquanto práxis educativa, visa estimular a práxis social, uma vez que esta "une compreensão teórica à ação real, com vistas à transformação radical da sociedade” (Vázquez, 1977).

Quanto às questões referentes à intervenção profissional, nos acostamos à opinião de Santos (2010, p. 96), ao dizer que "é urgente a necessidade de se conhecer a intervenção do Serviço Social, incluindo os instrumentais necessários a essa intervenção". Para a autora, o que existe hoje não é mais a necessidade de mudança de currículo, mas a aproximação da academia à realidade posta aos "profissionais da intervenção". Daí entendermos que se na prática o assistente social já se depara e atua com a educação popular ou pode criar possibilidades de atuar fundamentado nela, os centros de formação profissional devem, por meio de pesquisas, aprender com a educação popular, mas também nela intervir, contribuir, viabilizando, assim, uma relação dialética e dialógica entre educação popular e Serviço Social e, quem sabe, a formação de assistentes sociais mais críticos, dialógicos, democráticos e de fato capacitados para impulsionar a consciência crítica, a participação política, a organização popular e uma cultura crítica democrática quando intervirem diretamente na classe trabalhadora.

Inclusive porque quando os intelectuais, e aqui se incluem os assistentes sociais, se reconhecem como classe trabalhadora, e não apenas como indivíduos 
ou profissionais detentores do saber, e defendem ideias em favor dessa classe, tornam-se indispensáveis ao grupo social excluído do sistema hegemônico e ameaçadores do grupo que dirige tal sistema. Ao atuarem, podem direcionar ideologicamente as camadas populares a se reconhecer como sujeitos histórico-sociais, contribuindo, assim, com a organização política da classe subalterna. Até porque qualquer ação educativa, por mais dialógica que possa ser, nunca será neutra.

E ainda que saibamos que o fazer profissional do assistente social se distingue da arena da militância política, e que sua profissão se configura como especialização da divisão social e técnica do trabalho, por isso mesmo seu exercício profissional é mediado por uma relação assalariada, entendemos aqui que sempre podemos nos posicionar contra a hegemonia da classe dominante, e, dentro das nossas possibilidades institucionais, nos dispor a participar efetivamente da construção da hegemonia das classes dominadas, conforme a opção do nosso Projeto Ético-Político Profissional. E nessa empreitada a educação popular é uma importante aliada, tanto no debate político-ideológico como no teórico-metodológico e técnico-operativo que se opõe à hegemonia dominante. Além disso, "se a educação sozinha não transforma a sociedade, sem ela, tampouco, a sociedade muda" (Freire).

Recebido em 10/6/2011 - Aprovado em 28/11/2011

\section{Referências bibliográficas}

ABESS - ASSOCIAÇÃO BRASILEIRA DE ENSINO DE SERVIÇO SOCIAL. Apresentação. Caderno Abess, São Paulo, n. 2, p. 3-4, 1988.

BEZERRA, Aída. As atividades em educação popular. In: BRANDÃO, Carlos Rodrigues. (Org.). A questão política da educação popular. 4. ed. São Paulo: Brasiliense, 1984.

CAMPOS, Edval B.; MACIEL, Carlos A. B. Conselhos paritários: o enigma da participação e da construção democrática. Serviço Social \& Sociedade, São Paulo, n. 55. p. 143-155, 1997.

CFESS - CONSELHO FEDERAL DE SERVIÇO SOCIAL. Código de ética profissional do assistente social. Brasília, 1993.

COUTINHO, Carlos N. Gramsci. Porto Alegre: LPM, 1981. (Col. Fontes do Pensamento Político.) 
FALEIROS, Vicente de Paula. Reconceituação do Serviço Social no Brasil: uma questão em movimento? Serviço Social \& Sociedade, São Paulo, n. 84. p. 21-36, 2005.

FERRARI, Alfonso Trujillo. Metodologia da ciência. 3. ed. Rio de Janeiro, 1974.

FREIRE, Paulo. Pedagogia do oprimido. Rio de Janeiro: Paz e Terra, 1977.

Desmistificação da conscientização. In: TORRES, C. A. Consciência e história: a práxis educativa de Paulo Freire. (Antologia de textos selecionados de Paulo Freire) Trad. Mônica M. Oliva. São Paulo: Loyola, 1979a. (Col. Paulo Freire n. 1.)

. Investigação e metodologia da investigação do "tema gerador". In: TORRES, C. A. Consciência e história: a práxis educativa de Paulo Freire. (Antologia de textos selecionados de Paulo Freire) Trad. Mônica M. Oliva. São Paulo: Loyola, 1979b. (Col. Paulo Freire n. 1.)

. Conscientização: teoria e prática da libertação — uma introdução ao pensamento de Paulo Freire. São Paulo: Centauro, 2001.

Pedagogia da autonomia: saberes necessários à prática educativa. 31. ed. Rio de Janeiro: Paz e Terra, 2005.

. Política e educação. 8. ed. São Paulo: Villa das Letras, 2007.

GADOTTI, Moacir. Perspectivas atuais da educação. Porto Alegre: Artes Médicas Sul, 2000.

; TORRES, G. Educação popular: utopia latino-americana. São Paulo: Cortez/Edusp, 1994.

GRAMSCI, Antonio. Concepção dialética da história. Trad. Carlos Nelson Coutinho. 10. ed. Rio de Janeiro: Civilização Brasileira, 1995.

. Cadernos do cárcere. Trad. Carlos Nelson Coutinho. 3. ed. Rio de Janeiro: Civilização Brasileira, 2004. v. 2.

GRUPPI, Luciano. O conceito de hegemonia em Gramsci. Trad. Carlos Nelson Coutinho. 4. ed. Rio de Janeiro: Edições Graal, 2000.

IAMAMOTO, Marilda Villela. Projeto profissional, espaços ocupacionais e trabalho do assistente social na atualidade. In: CFESS. Atribuições privativas do(a) assistente social em questão. Brasília, 2002.

. Serviço Social em tempo de capital fetiche: capital financeiro, trabalho e questão social. 4. ed. São Paulo: Cortez, 2010.

KONDER, Leandro. O futuro da filosofia da práxis: o pensamento de Marx no século XXI. 2. ed. Rio de Janeiro: Paz e Terra, 1992. 
MARX, Karl; ENGELS, Friedrich. A ideologia alemã: Feuerbach - a oposição entre as cosmovisões materialista e idealista. Trad. Franck Müller. São Paulo: Martin Claret, 2005. (Col. A Obra Prima de Cada Autor.)

MELO NETO, J. F. Extensão universitária, autogestão e educação popular. João Pessoa: Editora Universitária/UFPB, 2004.

NETTO, José Paulo. Ditadura e serviço social: uma análise do Serviço Social no Brasil pós-64. 6. ed. São Paulo: Cortez, 2002.

NOGUEIRA, M. A. Um Estado para a sociedade civil: temas éticos e políticos da gestão democrática. São Paulo: Cortez, 2004.

PINTO, Álvaro Vieira. Sete lições sobre educação de adultos. 13. ed. São Paulo: Cortez, 2003.

PORTELLI, Hugues. Gramsci e o bloco histórico. Trad. Angelina Peralva. Rio de Janeiro: Paz e Terra, 1977.

SANTOS, Cláudia Mônica dos. Na prática a teoria é outra? Mitos e dilemas entre teoria, prática, instrumentos e técnicas no serviço social. Rio de Janeiro: Lumes Juris, 2010.

SIMIONATTO, Ivete; NOGUEIRA, Vera Maria Ribeiro. Pobreza e participação: o jogo das aparências e as armadilhas do discurso das agências multilaterais. Serviço Social \& Sociedade, São Paulo, n. 66. p. 145-164, 2001.

VÁZQUEZ, Adolfo S. Filosofia da práxis. 2. ed. Trad. Luiz F. Cardoso. Rio de Janeiro: Paz e Terra, 1977. 